\title{
Satellite Association and Structnral Anomalies in Two North Indian Populations-Rajputs and Punjabis
}

\author{
P. K. GHOSH \& Indera P. SingH \\ Department of Enthropology, Delhi University
}

\begin{abstract}
An attempt has been made to study the morphological variability of the human chromosomes in two Indian popnlations-Rajputs and Punjabis with respect to satellite association and the structural anomalies.
\end{abstract}

\section{INTRODUCTION}

Morphological variability of the human chromosomes are restricted to the heterochromatic regions, especially in the short arms of the acrocentric chromosomes. To study this chromosome polymorphism in Rajputs and Punjabis, two important parameters viz. satellite association and structural anomalies were investigated in detail.

I. Satellite association: The distributional studies of human chromosomes in metaphase plate have shown that the acrocentric chromosomes tend to lie near the middle of the nucleus (BARTon et al.; 1965, Galperin, 1968). These acrocentric chromosomes show an association pattern which was first reported by FERGUSONSMith and HandMAKER (1961) and confirmed by Merrington and Penrose (1969), Reitalu (1965) and Bishun (1966).

The only population study available with respect to satellite association is that of CoHen and SHAw (1967) who have studied five ethnic groups and have reported non-significant differences in between these groups. An attempt has been made in the present study to use satellite association as a criterion for studying population differences.

A number of factors like technique, physical and chemical agents, age, sex and clinical disorders have been reported by different authors and these are said to increase or decrease the frequency of acrocentric chromosomal association.

With regard to the technique used, $\mathrm{BACK}$ and $Z_{A N G}(1969)$ have reported significantly higher association pattern in macro-culture as compared to microcultures but, on the contrary, HANSSON (1970 b) has reported microcultures showing an increase in the percentage of cells with association complexes when compared with macrocultures. NANKIN (1971) has observed that the reduction of sedium citrate concentration in the hypotonic solution results in the decrease of satellite association frequency. NANKin (1970) and Mueller (1971) have also reported that the occurrence of association depends on the duration of culture. The association of acrocentric chromosomes also depends on the type of tissue, viz., blood or skin used in culture (Froland and Mikkelsen, 1964; 
Prokofieva-Belyovskaya et al., 1968).

Chemical and physical agents are strong factors influencing the association phenomenon considerably as reported by MERZ and Prempre (1966), Luchsinger et al. (1969), MCQuARrie et al. (1970) and HoeHn et al. (1971). The capacity of the acrocentric chromosomes to form association depends on the stage of ontogenesis (ARAgatsuni, 1967, 1969 ; Prokofieva-BelgovSKAYA et al., 1968; BogomAzov and DoroShenko, 1968; Mueller, 1971; Cooke, 1972). Z ZANG and BACK (1968) observed non significant sex differences in the satellite association pattern. On the contrary, GaLPERIN (1968) and Rosenkranz and HOLZER (1972) have observed the association tendency to be greater in females as compared to males.

An increased frequency of satellite association were observed in clinical cases arising from mitotic and meiotic nondisjunction (LyoNs et al., 1965; ZeLLWEGER et al., 1966; LUCHSINGER et al., 1969; RoSENKRANZ and FLECK, 1969 ; ZhDANOVA, 1971; Rosenkranz and Holzer, 1972). Contrary to this, Froland and Mikkelsen (1964) and BACK and ZANG (1969) have found no difference in frequency of associations in cases arising from nondisjunction error as compared to normal controls. HANSSON (1970 a) observed association complexes to be more heterogenous in mentally retarded patients as compared to normal controls. NANKIN et al. (1968) have observed that the satellite association occurs in normal and hyperthyroid females with equal frequency. The $\mathrm{Ph}^{+1}$ and $\mathrm{Ph}^{1-}$ cells have been found to differ significantly in their association pattern in a female patient with chronic myelogenous Leukemia (KITCHIN and SHAW, 1971).

Analysis of metaphases for satellite associations from women taking oral contraceptives and those taken as control show a significantly higher frequency of $\mathrm{D}-\mathrm{D}$ associations in women taking the "pill" compared to the controls. (McQuarRIE, 1970).

Non-random participation of acrocentric chromosomes have been reported by NAKAGOME and BLoOM (1970), Cooke (1971), Patil and Lubs (1971) and NAKAgome (1973). In contradiction with this, SHAW et al. (1969) have reported that the D group chromosomes do randomly involve, both in DD and DG associations.

II. Structural anomalies: It is usual for a small number of cells in the normal cell lines of an individual to show some structural anomalies like chromatid or chromosome gap or break. The cause of the existence of this kind of cells in normal individuals is not known, but a variety of chemical and physical mutagens (to which the civilized man is exposed) might be one reason (BLоom et al., 1970). Over 80 physical, chemical and biological agents have been shown to induce chromosomal aberration in human somatic cells (SHAw, 1970). Many mechanisms by which damage is caused to chromosomes have been postulated. Some of these include a direct virus " attack" or its combination with chromosome or else interference with DNA synthesis (NICHOLs, 1966). 
The structural anomalies of one or the other type in normal populations have been reported by different authors (BLOOM and TJio, 1964 ; Court Brown et al., 1966, Lubs and SAmuelson, 1967 ; Amarose and SChUSTER, 1971; BrogGer, 1971; Müller, 1971, Mehes cf. Müller, 1971 and LitTLEFIELD and GoH, 1973).

Bloom et al. $(1970,1973)$ have studied the structural anomalies in the Yanomama and Piaroa Indians of Venezuela and have observed that there is a progressive decline in the percentage of cells with structural anomalies in successive years 1969, 1970 and 1971 for which they have concluded that this decrease in the frequency is a result of the elimination of chromosomally damaged cells after exposure to a chromosome breaking agent.

\section{MATERIALS \& METHODS}

Rajputs and Punjabis are two endogamous groups of North and North-West India. Rajputs are divided into several subcastes or gotras which intermarray. Khatris and Aroras are two subcastes in Punjabis among whom inter-marriage is prevalent in recent times. Blood samples of 100 Rajputs and 100 Punjabis (Khatris and Aroras) have been collected from Blood Bank Transfusion Centre, Army Base Hospital, Delhi Cantonment during August, 1971 and December, 1973. In order to study the morphological variability of human chromosomes in these two groups, metaphase preparations were made from leucocyte cultures of these samples according to the method of MOORHEAD et al. (1960) with slight modifications. TC
199 was used as culture medium supplemented by $20 \%$ fetal calf serum. 1000 units of penicillin and $1000 \mathrm{mcg}$ of streptomycin each were used as antibiotics. Phytohemagglutinin-M $(0.2 \mathrm{ml})$ was used to initiate cell division. The culture were

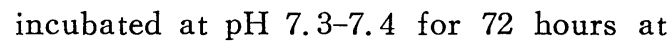
a temperature of $37^{\circ} \mathrm{C}$. At 70 hours 0.2 $\mu \mathrm{g} / \mathrm{ml}$. of calcemide was added to the culture and it was further incubated for 2 hours. Hypotonic treatment was then performed for 30 minutes using $0.075 \mathrm{M}$ $\mathrm{KCl}$. The materials were then fixed in $1: 3$ acetic acid-methyl alcohol fixative. The slides were made by air-drying method and stained in buffered Giemsa. Photomicrographs of five wellspread metaphases from each individual have been taken. The scoring of the metaphases for satellite association and structural anomalies were done as follows:

Two or more acrocentric chromosomes were considered "associated" when the following conditions laid down by $Z_{\text {ANG }}$ and BACK (1968) were fulfilled:

1) The distance between the two acrocentric chromosomes did not exceed the length of the long arm of the largest $G$ chromosome of the mitosis in question.

2) If the short arms of these chromosomes were connected by clearly visible thread like structures, larger distances were accepted.

3) Larger distances, up to the length of the long arm of a $\mathrm{D}$-chromosome, are also accepted when the associating patterns lies exactly on the same longitudinal axis. 4) The short arm of the second, or any further associating acrocentric chromo- 
somes, pointed towards those of the first and did not lie below the "centromereline" of the first chromosome. $Z_{\text {ANG }}$ and BACK (1968) defined "centromere-line" as the line that crosses the centromere perpendicular to the chromosomal longitudinal axis.

Spontaneous structural anomalies in the normal cell line were scored in the following manner: A gap was recorded when the chromosome showed an achromatic segment in the course of the chromatids, without displacement of the distal chromatid part, when only one of the chromatids showed an achromatic segment in the same region it was called a chromatid gap. A break was defined by a complete separation of continuity in the course of the chromatids with a diverging axis of the two chromatid parts concerned and/or a displacement of the distal part. When only a single chromatid was involved, it was called a chromatid break, but when both the sister chromatids appeared to be separated in the same region and displaced from the parent it was called a chromosome break.

Cells were also classified as hypomodal and hypermodal according whether the number of chromosome is less than or more than the modal number 46 respectively.

\section{RESULTS AND DISCUSSION}

I. Satellite Association: A total of 434 and 413 associations of acrocentric chromosmes have been observed in a set of 500 metaphases from 100 Rajputs and 500 metaphases from 100 Punjabis respectively. The percentage of cells showing at least one association of acrocentric chromosomes is found to be 65.0 per cent among Rajputs and 61.0 per cent among Punjabis (Table 1). The highest percentage of cells showing association of acrocentric chromosomes is reported by COHEN and SHAW (1967) in 96.4 per cent of the total metaphases studied by them and the lowest by ZELLWEGER et al. (1966) in 13.3 per cent of the total metaphases (Table 2).

The maximum number of cells show only one association of acrocentric chromosomes (46.0 per cent in Rajputs and 41.4 per cent in Punjabis), followed by two associations of acrocentric chromosomes (16.2 per cent in Rajputs and 17.8 per cent in Punjabis) as shown in table 3. Majority of the associations are formed by two chromosomes. (77.8 per cent in

Table 1. Frequency of cells showing association of acrocentric chromosomes.

\begin{tabular}{lcccc}
\hline Population & $\begin{array}{l}\text { No. } \\
\text { studied }\end{array}$ & $\begin{array}{l}\text { No. of } \\
\text { metaphases } \\
\text { observed }\end{array}$ & $\begin{array}{l}\text { Cells showing } \\
\text { association of } \\
\text { acrocentric } \\
\text { chromosomes }\end{array}$ & $\begin{array}{l}\text { Cells with no associa- } \\
\text { tion of acrocentric } \\
\text { chromosomes }\end{array}$ \\
\hline Rajputs & 100 & 500 & 325 & $\begin{array}{c}175 \\
(65.0)\end{array}$ \\
Punjabis & 100 & 500 & $\begin{array}{c}305 \\
(61.0)\end{array}$ & $(395.0)$ \\
\hline
\end{tabular}

Figures in parenthesis indicate percentage. 
Table 2. Percentage of association of acrocentric chromosomes in human lymphocyte metaphases as reported by different studies.

\begin{tabular}{|c|c|c|}
\hline No. & Authors & $\begin{array}{l}\text { Percentage of cells } \\
\text { with association }\end{array}$ \\
\hline & ZELLWEGER et al. (1966) & 13.5 \\
\hline & NANKIN et al. (1968) & 43.5 \\
\hline & FERGUSTN-SMith and HANDMAKER (1961) & 60.0 \\
\hline & Present study-Punjabis & 61.0 \\
\hline & Present study-Rajputs & 65.0 \\
\hline & Prakofieva-Belgovskaya et al. (1968) & 68.4 \\
\hline & ZANG and BACK (1968) & 87.1 \\
\hline & NANKIN $(1970)$ & 89.9 \\
\hline & COHEN and SHAW (1667) & 96.4 \\
\hline
\end{tabular}

Table 3. Distribution of cells with different number of association of acrocentric chromosomes.

\begin{tabular}{ccc}
\hline Type of Cells & Rajputs & Punjabis \\
\hline Cells with no AAC & 176 & 195 \\
Cells with 1 AAC & $(35.0)$ & $(39.0)$ \\
Cells with 2 AAC & 230 & 207 \\
& $(46.0)$ & $(41.4)$ \\
Cells with 3 AAC & 81 & 89 \\
Cells with 4 AAC & $(16.2)$ & $(17.8)$ \\
& $(2.8)$ & 8 \\
Total & - & $(1.6)$ \\
& & $(0.2)$ \\
\hline
\end{tabular}

Rajputs and 79.42 per cent in Punjabis) as shown in Table 4. Other studies show the same pattern except that of CoHeN and SHow (1967) in which the majority of the associations are formed by four chromosomes (38.33 per cent).

The involvement of $\mathrm{D}$ and $\mathrm{G}$ chromosomes in association of acrocentrics is shown in Table 5 . It may be seen from Table 5 that the $\mathrm{D} / \mathrm{G}$ type of association predominate (41.01 per cent in Rajputs and 43.58 per cent Punjabis), followed by D/D (23.04 per cent in Rajputs and 23. 49 per cent in Punjabis) and G/G (13.82 per cent in Rajputs and 12.35 per cent in Punjabis) type of associations. All other types of associations combined together account for 22.12 per cent of associations in Rajputs and 20.58 per cent of the associations in Punjabis. The same trend is observed in other studies except that of Cohen and Shaw (1967) and Cooke (1972) where the frequency of "others" type of associations is 73.261 per cent and 61.392 per cent respectively.

Rajputs and Punjabis are compared with 
Table 4. Number of chromosomes per association of acrocentric chromosomes.

\begin{tabular}{|c|c|c|}
\hline Type of association & Rajputs & Punjabis \\
\hline Association formed by two chromosomes & $\begin{array}{c}338 \\
(77.88017)\end{array}$ & $\begin{array}{c}328 \\
(79.41882)\end{array}$ \\
\hline Association formed by three chromosomes & $\begin{array}{c}73 \\
(16.82026)\end{array}$ & $\begin{array}{c}54 \\
(13.07504)\end{array}$ \\
\hline Association formed by four chromosomes & $\begin{array}{c}16 \\
(3.68662)\end{array}$ & $\begin{array}{c}26 \\
(6.29539)\end{array}$ \\
\hline Association formed by five chromosomes & $\begin{array}{c}5 \\
(1.15206)\end{array}$ & $\begin{array}{c}4 \\
(0.96852)\end{array}$ \\
\hline Association formed by seven chromosomes & $(0.46052)$ & - \\
\hline Association formed by eight chromosomes & - & $\begin{array}{c}1 \\
(0.24213)\end{array}$ \\
\hline Total & $\begin{array}{c}500 \\
(100.0)\end{array}$ & $\begin{array}{c}500 \\
(100.0)\end{array}$ \\
\hline
\end{tabular}

Table 5. Distribution of the association of the acrocentric chromosomes by the group to which associating chromosomes belong.

\begin{tabular}{|c|c|c|c|c|}
\hline \multirow{2}{*}{ Type of association } & \multicolumn{2}{|c|}{ Rajputs } & \multicolumn{2}{|c|}{ Punjabis } \\
\hline & No. & $\%$ & No. & $\%$ \\
\hline DD & 100 & 23.04147 & 97 & 23.48668 \\
\hline DG & 178 & 41.01382 & 180 & 43.58353 \\
\hline GG & 60 & 13.82488 & 51 & 12.34866 \\
\hline DDD & 11 & 2.53456 & 6 & 1.45278 \\
\hline DDG & 41 & 9.44700 & 26 & 6.29539 \\
\hline DGG & 17 & 3.91705 & 18 & 4.35835 \\
\hline GGG & 4 & 0.92165 & 4 & 0.96852 \\
\hline DDDD & 1 & 0.23041 & - & - \\
\hline DDDG & 1 & 0.23041 & - & - \\
\hline DDGG & 11 & 2.53456 & 17 & 4.11622 \\
\hline DGGG & 3 & 0.69124 & 1 & 0.24213 \\
\hline DDDDG & - & - & 1 & 0.24213 \\
\hline DDDGG & 1 & 0.24213 & 1 & 0.24213 \\
\hline DDGGG & 4 & 0.92165 & 1 & 0.24213 \\
\hline DGGGG & - & - & 1 & 0.24213 \\
\hline DDDDGGG & 1 & 0.23041 & - & - \\
\hline DDDGGGG & 1 & 0.23041 & - & - \\
\hline DDDDDGGG & - & - & 1 & 0.24213 \\
\hline Tatal & 434 & 99.99993 & 413 & 99.99995 \\
\hline
\end{tabular}

each other in relation to the distribution rest of the associations are put together of association complexes (Table 6). The and named as "others". Rajputs and distribution of the association complexes Punjabis show statistically non-significant made of two chromosomes like $\mathrm{D} / \mathrm{D}, \mathrm{D} / \mathrm{D}$ differences among themselves in relation and $\mathrm{G} / \mathrm{G}$ are taken separately whereas the to the distribution of association com- 
Table 6. Comparison of Rajputs and Punjabis in relation to the distribution of association complexes.

\begin{tabular}{|c|c|c|c|c|c|c|c|}
\hline \multirow{2}{*}{ Population } & \multicolumn{4}{|c|}{ Association type } & \multirow{2}{*}{$\begin{array}{l}\text { Total } \\
\text { AAC }\end{array}$} & \multirow{2}{*}{ Chi-square } & \multirow{2}{*}{$P(d . f .=3$} \\
\hline & $\mathrm{DD}$ & DG & GG & "Others" & & & \\
\hline Rajputs & 100 & 178 & 60 & 96 & 434 & \multirow{2}{*}{0.9350} & \multirow{2}{*}{$.90>P>.80$} \\
\hline Punjabis & 97 & 180 & 51 & 85 & $413\}$ & & \\
\hline
\end{tabular}

Table 7. Comparison of Punjabis with other world populations in

\begin{tabular}{|c|c|c|c|}
\hline No. Population & Authors & $\begin{array}{l}\text { No. of } \\
\text { individuals } \\
\text { studied }\end{array}$ & $\begin{array}{l}\text { No. of } \\
\text { metaphases } \\
\text { observed }\end{array}$ \\
\hline 1. Russian & Prokofieva-BelgovskayA et $a l$. (1968) & $385^{x}$ & 1235 \\
\hline 2. English I & FERGUSON-SMITH and HANDMAKER (1961) & $5 \sigma^{\top}$ & 250 \\
\hline 3. Sweedish I & HANSSON (1970 a) & $7 \sigma^{7} .4$ 우 & 1100 \\
\hline 4. Sweedish II & HANSSON $(1970 \mathrm{~b})$ & $20^{\top} .5$ 우 & 700 \\
\hline 5. English II & CoоKe (1972) & * & 1613 \\
\hline $\begin{array}{l}\text { 6. Indians } \\
\text { Japenese } \\
\text { Negroes } \\
\text { Jews } \\
\text { Non-jews }\end{array}$ & COHEN and SHAW (1967) & $100 \varsigma^{\top}$ & 1000 \\
\hline 7. Mexican & CuEvas-SosA (1970) & $1 \Im^{\top} .19$ & 300 \\
\hline 8. Punjabis & Present study & 100. $\sigma^{\top}$ & 500 \\
\hline
\end{tabular}

* Not known. Figures in parenthesis indicate percentage.

Table 8. Comparison of Rajputs with other world population in

\begin{tabular}{|c|c|c|c|}
\hline No. Population & Authors & $\begin{array}{l}\text { No. of } \\
\text { individuals } \\
\text { studied }\end{array}$ & $\begin{array}{l}\text { No. of } \\
\text { metaphases } \\
\text { observed }\end{array}$ \\
\hline 1. Russian & ProKofiEva-BELGovsKAYA (1968) & $380^{7}$ & 1235 \\
\hline 2. Enhlish I & FERGUSON-SMITH and HANDMAKER (1961) & $50^{x}$ & 250 \\
\hline 3. Sweedish I & HANSSON (1970a) & $70^{7} .4$ 우 & 1100 \\
\hline 4. Swesdish II & HANSSON $(1970 \mathrm{~b})$ & $2 \sigma^{\top} \cdot 5$ 우 & 700 \\
\hline 5. Enhlish II & СоОКЕ (1972) & * & 1613 \\
\hline $\begin{array}{l}\text { 6. Indians } \\
\text { Japanese } \\
\text { Negroes } \\
\text { Jews } \\
\text { Non-Jews }\end{array}$ & COHEN and SHAw (1967) & $1000^{x}$ & 1000 \\
\hline 7. Mexican & CUEvas-SosA (1970) & $15^{\top} \cdot 1$ 우 & 300 \\
\hline 8. Rajputs & Present study & 100. $0^{\pi}$ & 500 \\
\hline
\end{tabular}

* Not known. Figures is parenthesis indicat percentage. 
plexes (chi-square $=0.9350$, d.f. $=3: 90>P$ statistically significant differences with $>$.80).

When Rajputs and Punjabis are comSwedish (Hansson, 1970 a, b), English (Copared with other populaeions in relation to the distribution of $D / D, D / G, G / G$ and OKE, 1972) as well as a pooled result got by combining Indians, Japanese, Negroes, "others" type of associations they show 1927). They also show statistically nonrelation to the distribution of association complexes.

\begin{tabular}{|c|c|c|c|c|c|c|}
\hline \multicolumn{4}{|c|}{ Association types } & \multirow{2}{*}{$\begin{array}{l}\text { Total } \\
\text { AAC }\end{array}$} & \multirow{2}{*}{$\begin{array}{l}\text { Chi- } \\
\text { square }\end{array}$} & \multirow{2}{*}{$P($ d. $f .=3)$} \\
\hline DD & DG & GG & "Others" & & & \\
\hline $\begin{array}{c}348 \\
(26.646)\end{array}$ & $\begin{array}{c}531 \\
(41.658)\end{array}$ & $\begin{array}{c}173 \\
(13.247)\end{array}$ & $\begin{array}{c}254 \\
(19.449)\end{array}$ & 1306 & 2. 2572 & $.70>P>.50$ \\
\hline $\begin{array}{c}47 \\
(21.560)\end{array}$ & $\begin{array}{c}98 \\
(44.954)\end{array}$ & $\begin{array}{c}34 \\
(15.596)\end{array}$ & $\begin{array}{c}39 \\
(17.890)\end{array}$ & 218 & 1.9361 & $.70>P>.50$ \\
\hline $\begin{array}{c}261 \\
(23.759)\end{array}$ & $\begin{array}{c}516 \\
(46.952)\end{array}$ & $\begin{array}{c}144 \\
(13.123)\end{array}$ & $\begin{array}{c}178 \\
(16.197)\end{array}$ & 1099 & 4. 1987 & $.30>P>.20$ \\
\hline $\begin{array}{c}180 \\
(27.565)\end{array}$ & $\begin{array}{c}298 \\
(45.636)\end{array}$ & $\begin{array}{c}90 \\
(13.017)\end{array}$ & $\begin{array}{c}85 \\
(13.017)\end{array}$ & 653 & 11. 3274 & $.02>P>.01$ \\
\hline $\begin{array}{c}729 \\
(11.992)\end{array}$ & $\begin{array}{l}1214 \\
(19.970)\end{array}$ & $\begin{array}{l}404 \\
(6.646)\end{array}$ & $\begin{array}{l}3732 \\
(61.392)\end{array}$ & 6079 & 268. 0745 & $\mathrm{P}>.001$ \\
\hline $\begin{array}{c}44 \\
(6.800)\end{array}$ & $\begin{array}{c}95 \\
(14.683)\end{array}$ & $\begin{array}{c}34 \\
(5.255)\end{array}$ & $\begin{array}{c}474 \\
(73.261)\end{array}$ & 647 & 282. 3994 & $\mathrm{P}>.001$ \\
\hline $\begin{array}{c}151 \\
(24.754)\end{array}$ & $\begin{array}{c}260 \\
(42.623)\end{array}$ & $\begin{array}{c}66 \\
(10.820)\end{array}$ & $\begin{array}{c}133 \\
(21.803)\end{array}$ & 610 & 0.8920 & $.90>P>.80$ \\
\hline $\begin{array}{c}97 \\
(23.487)\end{array}$ & $\begin{array}{c}180 \\
(43.584)\end{array}$ & $\begin{array}{c}51 \\
(12.349)\end{array}$ & $\begin{array}{c}85 \\
(20.581)\end{array}$ & 413 & & \\
\hline
\end{tabular}

relation to the distribution of Association complexes.

\begin{tabular}{|c|c|c|c|c|c|c|}
\hline \multicolumn{4}{|c|}{ Association types } & \multirow{2}{*}{$\begin{array}{l}\text { Total } \\
\text { AAC }\end{array}$} & \multirow{2}{*}{$\begin{array}{l}\text { Chi- } \\
\text { square }\end{array}$} & \multirow{2}{*}{$P($ d. $f .=3)$} \\
\hline DD & $\mathrm{DG}$ & GG & "Others" & & & \\
\hline $\begin{array}{c}348 \\
(26.646)\end{array}$ & $\begin{array}{c}531 \\
(40.658)\end{array}$ & $\begin{array}{c}173 \\
(13.347)\end{array}$ & $\begin{array}{c}254 \\
(19.449)\end{array}$ & 1306 & 2. 8909 & $.50>P>.30$ \\
\hline $\begin{array}{c}47 \\
(21.560)\end{array}$ & $\begin{array}{c}98 \\
(44.954)\end{array}$ & $\begin{array}{c}34 \\
(15.596)\end{array}$ & $\begin{array}{c}39 \\
(17.890)\end{array}$ & 218 & 2. 2433 & $.70>P>.50$ \\
\hline $\begin{array}{c}261 \\
(23.759)\end{array}$ & $\begin{array}{c}516 \\
(46.952)\end{array}$ & $\begin{array}{c}144 \\
\text { (13.123) }\end{array}$ & $\begin{array}{c}178 \\
(16.197)\end{array}$ & 1099 & 8. 7188 & $.05>P>.02$ \\
\hline $\begin{array}{c}180 \\
(27.565)\end{array}$ & $\begin{array}{c}298 \\
(45.636)\end{array}$ & $\begin{array}{c}90 \\
(13.783)\end{array}$ & $\begin{array}{c}85 \\
(13.017)\end{array}$ & 653 & 16. 3177 & $\mathrm{P}>.001$ \\
\hline $\begin{array}{c}729 \\
(11.992)\end{array}$ & $\begin{array}{l}1214 \\
(19.970)\end{array}$ & $\begin{array}{l}404 \\
(6.646)\end{array}$ & $\begin{array}{l}3732 \\
(61.392)\end{array}$ & 6079 & 258. 3840 & $\mathrm{P}>.001$ \\
\hline $\begin{array}{c}44 \\
(6.800)\end{array}$ & $\begin{array}{c}95 \\
\text { (14. } 683)\end{array}$ & $\begin{array}{c}34 \\
(5.255)\end{array}$ & $\begin{array}{c}474 \\
(73.261)\end{array}$ & 647 & 273. 5273 & $\mathrm{P}>.001$ \\
\hline $\begin{array}{c}151 \\
(24.754)\end{array}$ & $\begin{array}{c}260 \\
(42.623)\end{array}$ & $\begin{array}{c}66 \\
(10.820)\end{array}$ & $\begin{array}{c}133 \\
(21.803)\end{array}$ & 610 & 2,4133 & $.50>P>.30$ \\
\hline $\begin{array}{c}100 \\
(23.042)\end{array}$ & $\begin{array}{c}178 \\
(41.014)\end{array}$ & $\begin{array}{c}60 \\
(13.825)\end{array}$ & $\begin{array}{c}96 \\
(22.120)\end{array}$ & 434 & & \\
\hline
\end{tabular}


significant differences with the Russian (Prokofieva-Belgovskaya et al., 1968), English (Ferguson-Smith and HandmaKER, 1961) and Mexican (Cuevas-Sosa, 1970) series (Table 7 and 8).

The functional significance of the phenomenon of "the association of acrocentric chromosomes" is still not clear. EDWARDS (1961) reports that the association of acrocentric chromosomes seems to be predominantly due to the association of the satellites. FERGuSON-SMith and HANDMAKER (1963) report that the association phenomenon may indicate the position of active nucleolus organiser sites. They also report that the chromosome associations are result of nucleolus fusion during interphase. Cooke (1972) reports that pattern of association is determined by the nucleolar organizing ability of the chromosomes.

“Nucleolus organiser sites are largely concerned with the mass production of ribosomal RNA, and are composed of repeated sequences which code for ribosomal percursors. Thus non-homologous chromosomes may have regions of homology at their nucleolus organiser sites. Non-homologous associations at meiosis could represent true synapsis between such regions, which then organise a common nucleolus. If true synapsis occurs, there is the possibility of rare accidental crossing-over between non-homologous which would lead to just the sort of rearrangement and polymorphism encountered" (FerGuson-Smith, 1967, 1972).

II. Structural anomalies and aneuploidy : Lymphocyte metaphases have been scored for aneuploidy as shown in Table 9. It may be seen from Table 9 that 98.00 per cent of Rajputs and 97.20 per cent of Punjabis have model cells while 1.80 per cent Rajputs and 2.40 per cent Punjabis have hypomodal cells. It is quite difficult to interpret the existence of aneuploid cells in normal cell lines. Technical factors seem to be the reason for the existence of hypomodal cells. The missing chromosomes being detached during preparation. Further, only two tetraploidal sets have been noticed in Punjabis, and

Table 9. Incidence of aneupoidy in the normal cell lines of Rajputs and Punjabis.

\begin{tabular}{|c|c|c|c|c|c|}
\hline \multirow{2}{*}{ Population } & \multirow{2}{*}{$\begin{array}{l}\text { Total number } \\
\text { of cells } \\
\text { observed }\end{array}$} & \multicolumn{4}{|c|}{ No. of chromosomes } \\
\hline & & 44 & 45 & 46 & 47 \\
\hline Rajputs & 500 & - & $(1 . \stackrel{9}{80})$ & $\begin{array}{c}490 \\
(98.00)\end{array}$ & $(0.20)$ \\
\hline Punjabis & 500 & $\left(\begin{array}{c}1 \\
20\end{array}\right)$ & $\begin{array}{c}12 \\
(2.40)\end{array}$ & $\begin{array}{c}486 \\
(97.20)\end{array}$ & $(0.20)$ \\
\hline
\end{tabular}

Figures in Parenthesis indicate percentages.

Table 10. The incidence of structural anomalies in Rajputs and Punjabis.

\begin{tabular}{llccc}
\hline Population & $\begin{array}{l}\text { No. of } \\
\text { individuals }\end{array}$ & $\begin{array}{l}\text { No. of metaphases } \\
\text { analysed }\end{array}$ & \multicolumn{2}{c}{$\begin{array}{l}\text { Cells with structural } \\
\text { anomalies }\end{array}$} \\
\hline Rajputs & 100 males & 500 & 19 & 3.8 \\
Punjabis & 100 males & 500 & 24 & 4.8 \\
\hline
\end{tabular}


two endoreduplication stages-one each from Rajputs and Punjabis have also been encountered.

The frequency of structural anomalies in Rajputs and Punjabis are listed in Table 10. Structural anomalies are recorded in 3.8 per cent of the metaphases in Rajputs and 4.8 per cent in Punjabis. Variable fiequencies of structural anomalies as repored by different studies in normal controls are listed in Table 11. The minimum frequency of structural anomalies are reported by BLOoM and
TJIO (1964) as 0.5 per cent in 1910 controle cells whereas the maximum frequency of 10.7 per cent of structural anomalies were observed out of a sample of 3720 cells derived from five male and five female controls (LuBS and SAMUELSON, 1967).

The incidence of different types of structural anomalies in Rajputs and Punjabis are listed in Table 12. Out of a total of 19 cells with aberrations in Rajputs, 11 have been found with chromatid gaps, 3 with chromosome gaps, 3 with chromatid

Table 11. Frequency of structural anomalies as reported by different studies.

\begin{tabular}{|c|c|c|c|c|}
\hline \multirow[t]{2}{*}{ References } & \multirow{2}{*}{$\begin{array}{l}\text { No. of } \\
\text { individuals } \\
\text { studied }\end{array}$} & \multirow{2}{*}{$\begin{array}{l}\text { No. of } \\
\text { metaphase } \\
\text { analysed }\end{array}$} & \multicolumn{2}{|c|}{$\begin{array}{l}\text { Cells with } \\
\text { structural } \\
\text { anomalies }\end{array}$} \\
\hline & & & No. & $\%$ \\
\hline BLOOM and TJIO (1967) & $*$ & 1810 & 9 & 0.5 \\
\hline BLоoм et al. (1970) & 174 Japanese & 16035 & 157 & 1.0 \\
\hline BLоOм et al. (1973) & $27 \underset{\text { Piaros I }}{\text { Indians }}$ & 2660 & 85 & 3.2 \\
\hline COURT BROWN et al. (1966) & 468 Individuals & 12420 & 417 & 3. 3 \\
\hline Mehes C.F. Mueller (1971) & $\begin{array}{l}11 \text { males } \\
11 \text { females }\end{array}$ & 6800 & 235 & 3.4 \\
\hline A.ULA (1965) & 10 Individuals & 1567 & 59 & 3.8 \\
\hline Rajputs-Present study & 100 males & 500 & 19 & 3.8 \\
\hline BLoom et al. (1970) & $49 \begin{array}{l}\text { Yanomama } \\
\text { Indians }\end{array}$ & 4875 & 200 & 4.1 \\
\hline MUELLER (1971) & 36 children & 4754 & 226 & 4.8 \\
\hline Punjabis-Presnt study & 100 males & 500 & 24 & 4.8 \\
\hline LitTLEFiELD and GOH (1973) & $\begin{array}{l}10 \text { males } \\
21 \text { females }\end{array}$ & 29709 & 1794 & 6.3 \\
\hline LUBS and SAMUELSON (1967) & $\begin{array}{l}5 \text { males } \\
5 \text { females }\end{array}$ & 3720 & 398 & 10.7 \\
\hline
\end{tabular}

* Not known.

Table 12. The incidence of different types of structural anomalies in Rajputs and Punjabis.

\begin{tabular}{lccccc}
\hline \multirow{2}{*}{ Population } & \multicolumn{3}{c}{ Cells with structural anomalies } \\
\cline { 2 - 5 } & \multicolumn{2}{c}{ Chromatid } & & \multicolumn{2}{c}{ Chromosome } \\
\cline { 2 - 5 } & Gap & Break & & Gap & Break \\
\hline Rajputs & 11 & 3 & 3 & 1 \\
Punjabis & 14 & 2 & 4 & 2 \\
\hline
\end{tabular}


Table 13. The frequency of differnnt types of structural anomalies as reported by various studies.

\begin{tabular}{|c|c|c|c|c|c|}
\hline References & $\begin{array}{l}\text { No, of } \\
\text { mataphases } \\
\text { analysed }\end{array}$ & $\begin{array}{l}\text { Chromatid } \\
\text { Gap }\end{array}$ & $\begin{array}{l}\text { Chromosome } \\
\text { Gap }\end{array}$ & $\begin{array}{l}\text { Chromatid } \\
\text { Break }\end{array}$ & $\begin{array}{l}\text { Chromosome } \\
\text { Break }\end{array}$ \\
\hline BLOOM and TJIO (1964) & 1810 & 9 & & & \\
\hline BLOOM et al. (1970) & 16035 & & & 105 & 23 \\
\hline BLoom et al. (1973) & & & & 45 & 22 \\
\hline CoURT BROWN et al. (1966) & 12420 & 277 & 83 & 38 & \\
\hline MEhes C. F. Mueller (1969) & 6800 & 93 & 15 & 102 & 13 \\
\hline AULA (1965) & 1567 & & & & 59 \\
\hline BLOOM et al. (1970) & 4875 & & & 112 & 33 \\
\hline MUELLER (1971) & 4754 & 162 & 11 & 32 & 8 \\
\hline LitTlefield and GOH (1973) & 29709 & & & & \\
\hline LuBSand SAmUELSON (1967) & 3720 & 165 & & 221 & 32 \\
\hline Rajputs-Present study & 500 & 11 & 3 & 3 & 1 \\
\hline Punjabis-Present Study & 500 & 14 & 4 & 2 & 2 \\
\hline
\end{tabular}

break and 1 with chromosome break. Further, 1 dicentric chromosome has been found in this series. Punjabis, on the other hand show 14 chromatid gaps, 4 chromosome gaps, 2 chromatid breaks, 2 chromosome breaks and 2 diacentric chromosomes out of a total of 24 cells with aberrations.

The frequency of different types of structural anomalies as reported by different studies of the world are listed in Table 13. It is observed from this table that exists a lot of spontaneous chromosome damage in the normal cell lines of normal individuals.

Chromosome breaks occur during the $\mathrm{G}_{1}$ phase while the chromosome is still functionally single while the chromatid breaks occur after chromosome reduplication during the $G_{2}$ phase and the $S$ phase. The exact mechanism by which these damages to chromosomes are caused is still unknown but cumulative exposure to a variety of agents in a total environment of man may bean important factor.

\section{SUMMARY}

In this paper, an attempt has been made to study the morphological variability of he human chromosomes in two Indian populations-Rajputs and Punjabis with respect to satellite association and the structural anomalies. The results are discussed in the light of findings revealed by different studies.

\section{NOTE}

The research work on which this paper is based was supported by C.S.I.R. grant no. 7/4 (458) 71-GAU. I.

\section{REFERENCES}

Amarose, A. P. and C. R. Sdhuster 1976: Chromosomal analysis of bone marrow and peripheral blood in subjects with a history of illicit drug use. Arch. Gen. Psychiat., 25: 181-186.

Aragatsuni, K. V. 1967: Association of acrocentric chromosomes in 80-86 year old per- 
sons. Genetika, 6: 79-85.

Aragatsuni, K. V. 1969: Association of human acrocentric chromosomes in newborns. $\mathrm{Zh}$. Eksp, Klin. Med., 9: 37-42.

AulA, P. 1965: Virus associated chromosome breakage: a cytogenetic study of chickenpox, measles and mumps patients and of cell culture infected with measles virus. Ann. Acad. Sic. Fenn., 489: 75.

BACK, E. and K.D. Zang. 1969: Quantative study on the arrangement of human metaphas chromosomes II influence of the preparation technique on the association pattern of the acrocentric chromosomes. Cytogenetics, 8 : 304-314.

BACK, E. and K. D. Zang. 1669: Studies on the arrangement of human metaphase chromosomes III. The association pattern of acrocentric chromosomes in mothers of mongoloid children and in controls. Humangengtik. 8: 47-52.

BARton, D. E., F. N. DAVID and M. MERRINGTON, 1965: The relatixe position of the chromosomes in the human cells in mitosis. Ann. Hum. Genet., 29 : 139-146.

BIshun, N.P. 1966: Arrociation of human satellited chromosomes. Experientia, 22:223225.

Bloom, A. D. and J.M. TJio, 1964: In vivo effects of diagnostic X-irradiation on human chromosomes. New Engl. J. Med., 270: 13411344 .

Bloom, A. D., J. V. NeEl, K. W. Chor, S. Lida and N. CHAGNON: Chromosome aberrations among the Yanomoma Indians. Proc. of the Nat. Acad. of Sci., 66:920-927.

Bloom, A. D., J. V. NeEl., T. TSUChimono and K. MEILINGER, 1973: Chromosomal breakage in lecuocytes of South American Indians. Cytogenet. Cell Genet., 12:175-186.

Bogomazov, E. A. and N. K. Doroshenko, 1963: Association of human satellite chromosomes depending on the age of the individual. Genetika. $4: 167-169$.

Cohen, M. W. and M. W. Shaw, 1967: The association of acrocentric chromosomes in 1000 normal human male metaphase cells.
Ann. Hum. Genet., 31: 129-140.

Cooke, P. 1971: Non-random participation of chromosomes 13,14 and 15 in acrocentric associations. Humangenetik, 13:309-314.

CoOKE, P. 1972: Age related variation in the number of Secondary associations between acrocentric chromosomes in normal females and patients with Turner's syndrome. Humangenetik, $17: 29-35$.

Court Brown, W.M., K.E. Budkton, P. A. JACOBS, I. M. TOUGH, E. V. KUENSBERG and I. D. E. KNox, 1966: Chromosome studies on adults. Eugenics Labs. Mem No. 42. Galton Labs., University College, London, Cambridge Univ. Press, London and New York.

Cuevas-Sosa A. 1970: Human chromosology: Random association of acrocentrics. Genetika, $41: 626-634$.

EDWARDS, J.H. 1961: Chromosomal association in man. Lancet I, 317-318.

FERGUSON-SMITH, M.A. and HANDMAKER, S.D. 1961: Observation on the satellited human chromosomes Lancet I. 638-640.

FERGUSON-Smith, M.A. and HANDMAKER, S.D. 1963: The association of satellited chromosomes with specific chromosomal regions in.cultured human somatic cells. Ann. Hum. Genet., 143-156.

Ferguson-Smith, M. A. 1967: Chromosomal satellite association Lancet I, 1156.

FERGUSON-Smith, M. A. 1972: Human chromosomes in meiosis. In "Human Genetics", pp. 195-211. Excerpta Medica, Amsterdam.

Froland, A. and M. Miknelsen, 1963: Studies on Satellite associations in human cells. Hereditas., 52: 248.

GAlperin, H. 1963: Comparative study of the association of human acrocentric chromosomes, in male and female mitosis. Cytogenetics, $7: 447-454$.

Galperin, H. 1960: Study of the general distribution of the 46 chromosomes in human metaphase plates. Humangenetik, 6:118-130.

HAnsSON, A. 1970 a: Differences in the Satellite association pattern in the human population. Hereditas, $66: 21-30$.

HANSSON, A. $1970 \mathrm{~b}$ : The influence of culture 
method on the satellite association pattern in human lymphocytes. Macro versus microcultures. Hereditas, $66: 31-34$.

Hoenn, H., M. Nagel and W. Krone, 1971: In vitro alteration of association patterns of human acrocentric chrosomes. Humangenetik, $11: 146-154$.

Kitchin, R. M. and M. W. Shaw, 1971: The association pattern of $\mathrm{Ph}^{1}$ chromosome. Cytogenetics, $10: 235-243$.

Litrlefield, L. G. and K. O. Goh. 1973: Cytogenetic studies in control men and women I variations in aberration frequencies in 29 ; 709 metaphases from 305 cultures obtained over a three year period. Cytogenet. Cell Genet., 12:17-34.
Lubs, H. A. and J. Samuelson, 1967: Chromosome abnormalities in lymphocytes from normal human subjects. Cytogenetics, $6: 402-411$. Luchsinger, U., E. Buhler, K. Kehes and G. STALDER, 1969: Satellits association in patients with chromosome anomalies and with hypothy reosis. Humangenetik, 8: 53-61.

LyONS, R. B., H. THOMPSON and R. H. BIGLEy, 1965: The sticky chromosome syndrome. Proc. Amer. Soc. Human Genet. 20:25.

MCQuarrie, H.G., C. D. Scolt, H.S. EllsWORTH, W. H., HARRIS and R. A. STONE 1970: Cytogenetic studies on women using oral contraceptives and their progeny. Amer. J. Obstet. Gynecol., 108: 659-665.

(Received February 9, 1976)

北部インド人二集団，ラジパット族とパンジャブ族の

付属性連合と構造的異常

$$
\begin{aligned}
& \text { ゴッシュ, P. K.・シン, I. P. } \\
& \text { デリー大学人類学教室 }
\end{aligned}
$$

ラジパット族とパンジャブ族の付属性連合と構造的異常を調べる目的で，ての二集団の人の染色体の形態的 変異を調べた。またその結果を，てれまで他の研究によって解明された知見と照して論じた。 